\title{
Hypocholesterolemic Effects of Lactobacillus casei subsp. casei TMC 0409 Strain Observed in Rats Fed Cholesterol Contained Diets
}

\author{
Hideo HASHIMOTO, Kazuyuki YAMAZAKI, Fang HE, Manabu KAWASE, \\ Masataka HOSODA and Akiyoshi HOSONO ${ }^{1}$ \\ Technical Research Laboratory, Takanashi Milk Products Co., Ltd., Asahi-ku, \\ Yokohama-shi 241-0023, Japan \\ ${ }^{1}$ Faculty of Agriculture, Shinshu University, Minamiminowa-mura, \\ Nagano-ken 399-4598, Japan
}

(Received September 21, 1998 ; Accepted December 22, 1998)

\begin{abstract}
In order to evaluate the hypocholesterolemic effect of Lactobacillus casei subsp. casei TMC 0409 strain (TMC 0409), an isolate from 'Dadih', an Indonesian traditional fermented dairy food, Sprague-Dawley rats were fed cholesterol containing diets supplemented with fermented milk cultured with TMC0409, skim milk and TMC 0409 lyophilized cells. No significant inhibitory effect was observed in the rats fed fermented milk and skim milk after 14 days feeding. But the increase of serum cholesterol was suppressed (36\%) in the rats fed TMC 0409 lyophilized cells. Total cholesterol, HDL-cholesterol, triglyceride and phospholipid in serum, neutral steroid and bile acids in feces, cholesterol and triglyceride in liver were analyzed in the rats fed TMC 0409 cells after 14 days feeding. Total cholesterol and phospholipid were significantly decreased compared to those of control group $(\mathbf{P}<0.01)$, however HDL-cholesterol was significantly increased $(P<0.05)$. Serum triglyceride was also decreased but the difference was not significant. From these results, the inhibition of increase of serum cholesterol in rats fed TMC 0409 cells was considered to have resulted from the reduction of LDL + VLDL-cholesterol. Meanwhile, the accumulation of triglyceride in the liver was inhibited significantly compared with the control group $(P<0.05)$, and the excretion of bile acid in the feces was also enhanced significantly $(P<0.01)$. These results imply that strain $T M C 0409$ can alter the serum cholesterol concentration, especially LDL + VLDL-cholesterol by enhancing the excretion of bile acids in the feces.
\end{abstract}

Animal Science Journal 70 (2) : 90-97, 1999

Key words : Hypocholesterolemic effect, Lactic acid bacteria, Lactobacillus casei subsp. casei TMC 0409 strain, Cholesterol

There is an apparent association between the high serum cholesterol and the development of coronary heart diseases. Therefore, keeping serum cholesterol in desirable level in the normal diet life is considered a practical preventive method for these diseases.

Fermented milk products has been well known for their benefits in the maintenance of human health and well being ${ }^{21)}$. Since Mann and Sperry's ${ }^{13)}$ initial in- vestigation in 1974, many studies have also been conducted to evaluate the hypocholesterolemic effect of fermented milks in animal and human ${ }^{1,4,8,18-20)}$. However, the results of these studies were not consistent. The hypocholesterolemic effect of the tested fermented milks greatly varied with the difference of lactic acid bacteria flora involved in these fermented milks. In order to obtain the expected

Corresponding : Akiyoshi HOSONO (fax : +81 (0) 265-76-1894, e-mail : ahosono@gipmc.shinshu-u.ac.jp)

Anim. Sci. J. $70(2): 90-97,1999$ 
hypocholesterolemic effect of fermented milk, utilization of the selected lactic acid bacteria, well characterized in vitro and in vivo, in fermented milk is necessary.

Lactobacillus casei subsp. casei TMC 0409 strain (TMC 0409) was isolated from Dadih, an Indonesian traditional fermented dairy food. In the previous comparative studies with our stock culture lactic acid bacteria, this bacterium exhibited the highest possibility to alter the serum cholesterol in rats ${ }^{6)}$. However, the hypocholesterolemic effect of TMC 0409 should be more characterized, as its related mechanism are still unclear.

In the present study, fermented milk cultured with strain TMC 0409, skim milk and TMC 0409 cells were compared for their abilities to alter the serum cholesterol level of the rats fed with cholesterol containing diet. Among the tested rats, the cholesterol concentration in the serum, liver and stool were analyzed in the rats fed TMC 0409 lyophilized cells.

\section{Materials and Methods}

\section{Bacterial Strain}

TMC 0409 strain was originally isolated from an Indonesian fermented dairy food 'Dadih' and identified as Lactobacillus casei subsp. casei based on the phenotype characters according to Bergey's Manual of Systemic Bacteriology (1986). Strain TMC 0409 is deposited in the culture collection of the laboratory of Takanashi Milk Products, Yokohama, Japan.

\section{Preparation of lyophilized cells}

TMC 0409 was inoculated into Lactobacilli MRS broth (Difco) and incubated at $37^{\circ} \mathrm{C}$ for 18 hours. After incubation, cells were harvested by centrifuging at $10,000 \times g$ for $10 \mathrm{~min}$, washed twice in sterile distilled water and then freeze-dried using the method described by Kozaki et al. 1986.

\section{Preparation of fermented milk}

The reconstituted skim milk (no fat solid : $8.0 \%$; sugar $8.0 \%$ ) containing $0.1 \%$ of soypeptide (Hainyuto-SMP, Fujiseiyu, Osaka, Japan) was pasteurized at $80^{\circ} \mathrm{C}$ and cooled to $37^{\circ} \mathrm{C}$. After inocu-

Table 1. Composition of experimental diets

\begin{tabular}{|c|c|c|c|c|}
\hline \multirow{2}{*}{ Constituent } & \multicolumn{4}{|c|}{ Diets $(\mathrm{g} / 100 \mathrm{~g})$} \\
\hline & Control & Diet $1^{3)}$ & Diet $2^{4)}$ & Diet $3^{5)}$ \\
\hline Casein & 20 & 20 & 20 & 20 \\
\hline Safflower oil & 10 & 10 & 10 & 10 \\
\hline Vitamin mixture ${ }^{1)}$ & 1 & 1 & 1 & 1 \\
\hline Mineral mixture & 4 & 4 & 4 & 1 \\
\hline Choline chloride & 0.2 & 0.2 & 0.2 & 0.2 \\
\hline Cellulose powder & 2 & 2 & 2 & 2 \\
\hline Cholesterol & 0.5 & 0.5 & 0.5 & 0.5 \\
\hline Sodium cholate & 0.125 & 0.125 & 0.125 & 0.125 \\
\hline Sucrose & 62.175 & 57.175 & 57. 175 & 57.175 \\
\hline Fermented milk & 0 & 5 & 0 & 0 \\
\hline Skim milk & 0 & 0 & 5 & 0 \\
\hline Bacterial cells & 0 & 0 & 0 & 5 \\
\hline Total & 100 & 100 & 100 & 100 \\
\hline
\end{tabular}

1),2);AIN-76

3) Diet 1: TMC0409 fermented milk

${ }^{4)}$ Diet 2 : Skim milk

${ }^{5)}$ Diet 3 : TMC 0409 lyophilized cells 


\section{HASHIMOTO, YAMAZAKI, HE, KAWASE, HOSODA and HOSONO}

lation with $3 \%$ TMC 0409 culture, the skim milk was incubated at $37^{\circ} \mathrm{C}$ for $18-20$ hours until $\mathrm{pH}$ became 4.5. The fermented milk was kept at $4^{\circ} \mathrm{C}$, until use.

\section{Diets}

Composition of diets is shown in Table 1 . Cholesterol containing diet which included $0.5 \%$ cholesterol and $0.125 \%$ sodium cholate, was used in this study based on the method of Nagata et al. ${ }^{16)}$. Fermented milk, skim milk and bacterial cells were added to the control diet at a level of $5 \%$, replacing an equal amount of sucrose.

\section{Animals}

Experimental animals consisted of 4-week-old male Sprague-Dawley rats (Japan Clea, Tokyo, Japan). After feeding standard diets (CA-1, Japan Clea, Tokyo, Japan) for one week, the rats were grouped according to their body weights (ten rats in each group) and housed in individual cages in an air conditioned room at $24 \pm 1^{\circ} \mathrm{C}$ with $55 \pm 5 \%$ humidity under a $12 \mathrm{~h}$ light cycle. The animals were given their respective diets and allowed tap water ad libitum. During the test period, body weight and intake of diets were recorded everyday. Rats were bled from orbital vein at 0 and abdominal aorta at 14 days for serum lipid analysis after fasting overnight. The liver was excised immediately, weighed and stored at $-20^{\circ} \mathrm{C}$ until lipid analysis. Feces were collected on the last 4 days of the experimental period and freeze-dried for 18 hours.

\section{Analyses of serum and liver lipids}

Total serum cholesterol concentration, triglycerides, HDL-cholesterol and phospholipid were analyzed using Cholesterol E Test Wako, Triglyceride G Test Wako, HDL-cholesterol Test Wako and Phospholipid C Test Wako (Wako pure chemical, Tokyo, Japan), respectively. Lipids from the liver was extracted as described by Folch et al. ${ }^{2)}$, and analyzed as noted above.

\section{Analysis of fecal steroids}

Aliquots of freeze-dried feces (0.1 g) were suspended in $2.5 \mathrm{ml}$ hot ethanol in a sealed tube and extracted at $80^{\circ} \mathrm{C}$ for one hour. After two extractions, the supernatant fraction was evaporated under nitrogen gas at $50^{\circ} \mathrm{C}$ and redissolved in $2 \mathrm{ml}$ ethanol. Concentrations of cholesterol and coprostanol in the feces were measured by gas-liquid chromatography (GLC). A11 GLC analyses were performed on an instrument equipped with a hydrogen flame ionization detector (G-3000, Hitachi seisakusyo, Tokyo, Japan). The columns were $30 \mathrm{~m}$ glass tubes, $0.25 \mathrm{~mm}$ i.d.

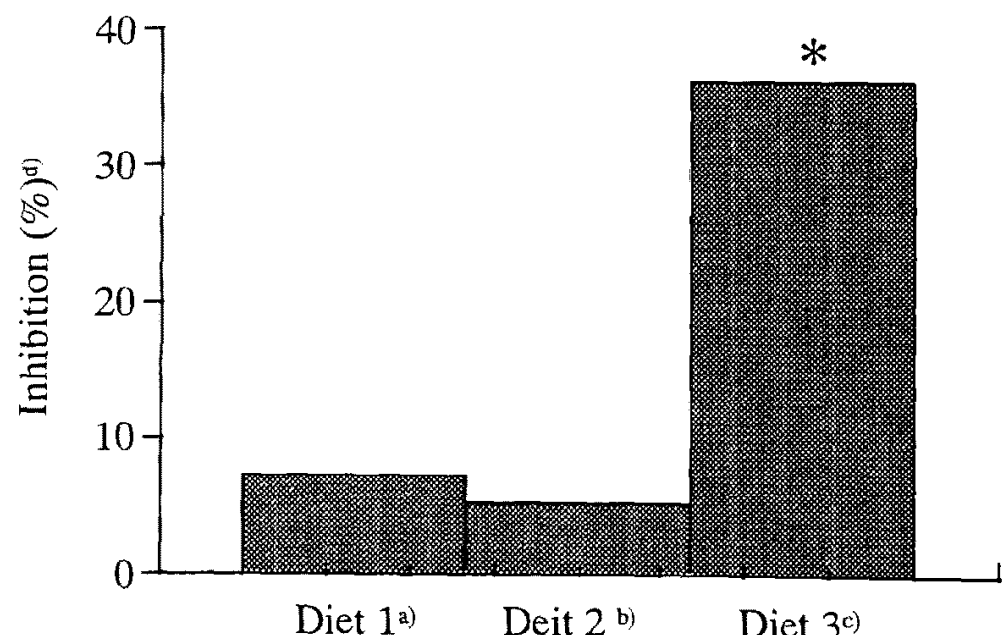

Fig. 1. Inhibitory effect of lactic acid bacteria containing diet on the increase of serum total cholesterol levels in Rats.

${ }^{\text {a) }}$ Diet 1 : TMC 0409 fermented milk, ${ }^{\text {b) }}$ Diet 2 : Skim milk, ${ }^{\text {c) }}$ Diet $3:$ TMC 0409 cells.

${ }^{d)}$ Inhítion $(\%)=[($ Control-Diet $) /$ Control $] \times 100$

Asterisks indicate significant difference from the control of table-1 $\left({ }^{*} \mathrm{P}<0.01\right)$.

Anim. Sci. J. 70 (2) : 90-97, 1999 
(DB $^{\mathrm{TM}}-17, \mathrm{~J} \& \mathrm{~W}$ Scientific, CA, USA). The column temperature were $240^{\circ} \mathrm{C}$, the temperature of the flash heater was $250^{\circ} \mathrm{C}$ and of the detector was $300^{\circ} \mathrm{C}$. He-gas was used as carrier gas at the flow rate of 43 $\mathrm{cm} / \mathrm{sec}$. Fecal bile acid was measured by commercial test kit (Enzabile II, Daiich Kagaku Yakuhin, Tokyo, Japan).

\section{Statistical analysis}

Experimental data is expressed as mean \pm S.E. Difference among groups was conducted using Student's $t$ test.

\section{Results}

Inhibitory effects of TMC 0409 fermented milk, skim milk and TMC 0409 cells on the increase of serum cholesterol level

In the present study, the body weight did not differ significantly among each group, although the three experimental groups exhibited higher weight gain than the control group.
After 14 days feeding, only slightly inhibitory effects on the increase of serum cholesterol level were observed in the rats fed fermented milk $\left(4.4 \times 10^{8} \mathrm{cfu} /\right.$ $\mathrm{ml}$ ) prepared with TMC 0409 and skim milk. However, the increase in total cholesterol was suppressed to $36 \%$ in the rats fed cholesterol containing diet supplemented with TMC 0409 cells $\left(3.4 \times 10^{10} \mathrm{cfu} / \mathrm{g}\right)$ compared to the control (Fig. 1).

\section{Serum cholesterol of rats fed TMC 0409 cells}

After 14 days feeding, serum total cholesterol, HDL-cholesterol, triglyceride, phospholipid concentration were analyzed in the rats fed cholesterol containing diets supplemented with or without TMC 0409 cells (Table 2). The total cholesterol level and phospholipid of the rats fed TMC0409 cells were significantly $(\mathrm{P}<0.01)$ lower than those of the control group. The HDL-cholesterol levels were significantly $(\mathbf{P}<0.05)$ increased compared to control group. The triglyceride levels were decreased but the difference was not significant between the two groups.

Table 2. Food intake, body weights, serum total cholesterol, HDL cholesterol, triglyceride and phospholipid concentrations of rats fed TMC 0409 cells

\begin{tabular}{rcc}
\hline & \multicolumn{2}{c}{ Groups } \\
\cline { 2 - 3 } & Control $(\mathrm{n}=10)$ & Diet $3(\mathrm{n}=10)$ \\
\hline Food intake 14 days $(\mathrm{g} / \mathrm{d})$ & $\left.19.85 \pm 0.79^{1}\right)$ & $20.60 \pm 0.65$ \\
Body weight gain $(\mathrm{g} / 14 \mathrm{~d})$ & $114.40 \pm 2.61$ & $118.70 \pm 2.53$ \\
Total cholesterol $(\mathrm{mg} / \mathrm{d} l)$ & & \\
0 day & $82.89 \pm 3.14$ & $76.27 \pm 4.43$ \\
14 day & $242.91 \pm 10.53$ & $155.80 \pm 11.15^{* *}$ \\
0 day & $32.16 \pm 0.95$ & $34.04+1.79$ \\
HDL-cholesterol $(\mathrm{mg} / \mathrm{d} l)$ & $22.78 \pm 0.76$ & $26.25 \pm 0.66^{*}$ \\
day & & \\
Triglyceride $(\mathrm{mg} / \mathrm{d} l)$ & $119.22 \pm 14.74$ & $100.88 \pm 10.84$ \\
14 day & $191.80 \pm 11.44$ & $172.15 \pm 15.86$ \\
0 day & $137.94 \pm 5.52$ & $123.64+3.97$ \\
14 day & $184.17 \pm 5.09$ & $133.04 \pm 5.55^{* *}$ \\
\hline
\end{tabular}

1) Values are means \pm SEM.

Asterisks indicate significant difference from the control $\left({ }^{*} \mathrm{P}<0.05\right.$, ** $\mathbf{P}<0.01)$. 
HASHIMOTO, YAMAZAKI, HE, KAWASE, HOSODA and HOSONO

Table 3. Liver weight and lipid levels in rats fed TMC 0409 cells

\begin{tabular}{lll}
\hline & \multicolumn{2}{c}{ Groups } \\
\cline { 2 - 3 } & \multicolumn{1}{c}{ Control $(\mathrm{n}=10)$} & \multicolumn{1}{c}{ Diet $3(\mathrm{n}=10)$} \\
\hline Liver weight $(\mathrm{g} / 100 \mathrm{~g}$ B.W. $)$ & $4.384 \pm 0.082^{1)}$ & $4.747 \pm 0.104^{*}$ \\
Cholesterol $(\mathrm{mg} /$ wet $\mathrm{g})$ & $32.86 \pm 19.70$ & $24.80 \pm 17.26$ \\
Triglyceride $(\mathrm{mg} /$ wet $\mathrm{g})$ & $82.40 \pm 18.61$ & $61.34 \pm 12.01^{*}$ \\
\hline
\end{tabular}

1) Values are means $I S E M$.

Asterisks indicate significant difference from the control $(* \mathrm{P}<0.05)$.

Table 4. Fecal neutral steroid and bile acid levels in rats fed TMC 0409 cells

\begin{tabular}{ccc} 
& & \multicolumn{2}{c}{ Groups } \\
\cline { 3 - 3 } & Control $(\mathrm{n}=10)$ & Diet $3(\mathrm{n}=10)$ \\
\hline Cholesterol $(\mu \mathrm{mol} / \mathrm{rat} / \mathrm{day})$ & & \\
Initial & $16.763 \pm 0.570^{13}$ & $18.037 \pm 0.938$ \\
Final & $31.879 \pm 3.293$ & $38.380 \pm 2.281$ \\
Coprostanol $(\mu \mathrm{mol} / \mathrm{rat} / \mathrm{day})$ & & \\
Initial & $17.445 \pm 1.008$ & $19.819 \pm 1.335$ \\
Final & $13.472 \pm 1.277$ & $7.979 \pm 1.370^{* *}$ \\
Neutral steroid $(\mu \mathrm{mol} / \mathrm{rat} /$ day $)$ & & \\
Initial & $34.208 \pm 1.335$ & $37.856 \pm 1.877$ \\
Final & $45.352 \pm 3.415$ & $46.359 \pm 2.788$ \\
Bile acid $(\mu \mathrm{mol} / \mathrm{rat} /$ day $)$ & & \\
Initial & $12.004 \pm 1.080$ & $13.221 \pm 0.941$ \\
Final & $13.547 \pm 1.243$ & $23.167 \pm 1.581 * *$ \\
Total steroid $(\mu \mathrm{mol} / \mathrm{rat} /$ day $)$ & & \\
Final & $46.212 \pm 2.137$ & $51.077 \pm 1.971$ \\
& $58.900 \pm 4.551$ & $69.525 \pm 2.830$ \\
\hline
\end{tabular}

1) Values are means \pm SEM.

Asterisks indicate significant difference from the control $(* * \mathrm{P}<0.01)$.

\section{Liver weight and cholesterol of rats fed TMC 0409 cells}

The results of liver weight and lipid levels of the rats fed TMC 0409 cells are presented in Table 3. The liver weight per body weight was significantly higher in the rats fed TMC 0409 cells than the control group $(\mathbf{P}<0.05)$. There was no significant difference in the levels of cholesterol between the two groups, whereas triglyceride level was significantly lower in the rats fed TMC 0409 cells than the control group $(\mathrm{P}<0.05)$.

\section{Fecal steroid of rats fed TMC 0409 cells}

After 14 days feeding, the fecal neutral steroid and bile acid concentration of the rats fed TMC0409 cells were analyzed (Table 4). No significant difference was observed in fecal neutral steroid between rats fed TMC 0409 cells and control group. However, bile acid in the feces was significantly higher in the rats fed TMC 0409 cells compared to that of the control group ( $\mathrm{P}<0.01)$. 


\section{Discussion}

'Dadih' is a popular fermented dairy product in West Sumatra of Indonesia, which has been consumed by local people and are generally believed to posses a health promoting effects on human being. Lactobacillus casei subsp. casei TMC 0409 strain (TMC 0409) was isolated from Dadih. Our previous studies on the potent ability of lactic acid bacteria to influence serum cholesterol metabolism revealed that TMC 0409 cells suppressed the increase of serum total cholesterol more effectively than other tested lactic acid bacteria $^{6)}$. In the present study, TMC0409 fermented milk and skim milk were tested for their abilities to alter serum cholesterol of the rats fed cholesterol containing diet. The fermented milk prepared with TMC 0409 strain and skim milk did not show significant inhibitory effects on the increase of serum cholesterol of the rats fed cholesterol containing diet, whereas the TMC0409 cells preparation significantly suppressed the increase of serum total cholesterol of rats fed cholesterol containing diet after 14 days of administration, which are consistent with our previous study ${ }^{6)}$. These results indicated that the hypocholesterolemic effect is mainly contributed by strain TMC0409 cells. In the present study, the impact of TMC 0409 cells on serum cholesterol metabolism of the rats fed cholesterol containing diet was evaluated after 14 days of intervention. Serum HDL-cholesterol was significantly increased, meaning that the decrease of total serum cholesterol by TMC 0409 cells is considered to result from the reduction of serum LDL + VLDL-cholesterol. These results indicate that TMC 0409 strain can alter serum LDL+ VLDL-cholesterol, as do other health promoting lactic acid bacteria ${ }^{1)}$. Moreover, the risk of arteriosclerosis is inversely proportional to the level of HDL. Thus, this strain may have a significant role in human health care.

The cholesterol concentration in serum is greatly influenced by the metabolism of bile acid and cholesterol in the intestine and liver. Dietary fiber and anion exchange resins can alter the scrum cholesterol of human and animal with their capacity to bind bile acids and excrete them through feces ${ }^{10-12,17,22)}$. The hypocholesterolemic effects of some lactic acid bacteria were also found to be related to their capacity to bind bile acids and cholesterol in their cells $\mathrm{s}^{5,9,14}$. Furthermore, the cholesterol-lowering effect of dictary fiber is also related to fermentation of the fed dietary fiber in the intestine by intestinal bacteria, which lead to the lowering of lumen $\mathrm{pH}$ and insulation of bile acid $^{7)}$. Some lactic acid bacteria have been found to survive in human intestine and alter intestinal environment such as $\mathrm{pH}$ and enzyme profile by their metabolism ${ }^{3)}$. These knowledge and findings lead to a hypothesis that lactic acid bacteria could exhibit practical hypocholesterolemic effects if they have a high ability to colonize in human intestine and bind with bile acid and cholesterol. In the previous study on screening lactic acid bacteria, TMC 0409 strain was found to possess the highest ability to bind bile acid in vitro than other stock cultures ${ }^{6)}$. Furthermore, TMC 0409 strain can also resist acid environment and adhere to human Caco- 2 cell line better than other tested strains ${ }^{6)}$. Caco-2 cell line is a human cell culture, which is widely used to evaluate the capacity of lactic acid bacteria to colonize in human intestine ${ }^{3)}$. The hypocholesterolemic effect of TMC 0409 cells observed in this study might be attributed to the activities of this bacterium in the intestine of the tested rats, colonizing in intestine, binding bile acid to their cells and elevating the excretion of this steroids into feces, like dietary fibers and ion exchange resins. This explanation was well supported by the fact that the fecal bile acids of rats fed TMC 0409 cells preparation were enhanced (Table 3 ). In the following studies, the fecal bacterial composition of rats and human subjects fed TMC 0409 cells preparation will be analyzed to confirm the colonization of TMC 0409 strain in the intestines of animal and human so that more reasonable conclusion could be made.

Mann and Spoerry ${ }^{13)}$ first reported the positive effects of the fermented milk in modifying the serum cholesterol in the epidemic study of 1970s. However, the results obtained from late studies aimed to clarify the hypocholesterolemic effect of fermented milk were controversial $1^{1,4,8,18-20)}$. In the recent study, whey protein exhibited stronger hypocholesterolemic effect in the rats fed cholesterol containing diet compared to 


\section{HASHIMOTO, YAMAZAKI, HE, KAWASE, HOSODA and HOSONO}

the casein protein and soy bean protein ${ }^{15)}$. No whey protein was added in the fermented milk and skim milk used in this study. As shown in our previous study ${ }^{6)}$, the hypocholesterolemic effect of TMC 0409 strain was dose-dependent. In the present study, the number of bacterial cell were $4.4 \times 10^{8} \mathrm{cfu} / \mathrm{ml}$ (fermented milk) and $3.4 \times 10^{10} \mathrm{cfu} / \mathrm{g}$ (TMC 0409 cells), respectively. Lactic acid bacteria cells in Diet 1 were $2.2 \times 10^{9} \mathrm{cfu} / 100 \mathrm{~g}$ and Diet 3 were $1.7 \times 10^{11}$ $\mathrm{cfu} / \mathrm{ml}$. These indicated that the cells preparation of TMC0409 showed the strongest inhibitory effect on the increase of serum cholesterol compared with the fermented milk prepared with TMC0409 strain and skim milk, indicating that the hypocholesterolemic effect to fermented milk are mainly determined by the activities of lactic acid bacteria involved in the fermented milk rather than the component of milk and metabolism produced in fermentation process. From these observation, we concluded that the wide variation of hypocholesterolemic effect of the fermented milk among the reported studies may be partly related to the differences of lactic acid bacteria involved in these fermented milk.

\section{Reference}

1) Akalin SA, Gong S, Duel S. Influence of yoghurt and acidophilus yoghurt on serum cholesterol levels in mice. Journal of Dairy Science, 80 : 2721-2725. 1997.

2) Folch J, Lees $M$, Sloane-Stanley GH. A simple method for the isolation and purification of total lipids from animal tissue. Journal of Biological Chemistry, $226: 497-509.1957$.

3) Goldin BR, Gorbach SL, Saxelin M, Baraskat S, Gualtieri L, Salminen S. Survival of Lactobacillus Specie (Strain GG) in human gastrointestinal tract. Digestive Diseases and Sciences, 37 : 121-128. 1992.

4) Gruenewald $\mathrm{K} K$. Serum cholesterol levels in rats fed skim milk fermented by Lactobacillus acidophilus. Journal of Food Science, 47 : 2078-2079. 1982.

5) Hartman RE, Holmlund C E. Binding of steroid by microorganisms. Journal of Bacteriology, 84 : 12541259. 1962

6) Hashimoto $\mathrm{H}$, Yamazaki $\mathrm{K}, \mathrm{He} \mathrm{F}$, Yasuko A, Kawase M, Hosoda M, Hosono A. Effect of lactic acid bacteria on serum cholesterol level in rats fed cholesterol diet. Animal Science and Technology, 69: 702-707, 1.998
7) Hassan Y, Lerrat MA, Pemigne C, Remesy C. Resistant starch is more effective than cholestyramine as lipid lowering agent in the rat. Lipids, $30: 847-853$. 1995.

8) Hepner G, Fried R, Jeor S, Fusetti L, Morin R. Hypocholesterolemic effect of yogurt and milk. American Journal of Clinical Nutrition, 32 : 19-24. 1979.

9) Hosono A, Tono-oka T. Binding of cholesterol with lactic acid bacterial cells. Milchwissenschaft, 50: 556-560. 1995.

10) Kihara $K$, Toda $H$, Mori $M$, Hashimoto $M$, Mizogami S. The bile acid binding and hypocholesterolemic activity of amino-exchange resins bearing the imidazolium salt group. European Journal of Medicinal Chemistry, $23: 411-415.1988$.

11) Kiriyama S, Okazaki Y, Yoshida A. Hypocholesterolemic effect of polysaccharides and polysaccharide-rich foodstuffs in cholesterol-fed rats. Journal of Nutrition, $97: 382-388,1969$.

12) Lindenbaum $S$, Higuchi T. Binding of bile acids to cholestyramine at gastric $\mathrm{pH}$ conditions. Journal of Pharmaceutical Sciences, 64: 1887-1889. 1975.

13) Mann GV, Spoerry A. Studies of a surfactant and cholesteremia in the Massai, American Journal of Clinical Nutrition, $27: 464-469.1974$.

14) Midtvedt $T$, Morman A. Adsorption of bile acids to intestinal microorganisms. Acta Pathologica et Microbiologica Scandinaviva [Section B], $80: 202$ 210. 1972.

15) Nagaoka S, Kanamaru $Y$, Kuzuya $Y$, Kojima $T$, Kuwata T. Comparative studies on the serum cholesterol lowering action of whey protein and soybean protein in rats. Bioscience Biotechnology and Biochemistry, $56: 1484-1485.1992$.

16) Nagata $Y$, Tanaka K, Sugano M. Serum cholesterol levels of rat and mice fed soy-been protein or casei. Journal of Nutritional Science and Vitaminology, 27 : 583-593. 1981.

17) Okenfull DG, Fenwick DE. Adsorption of bile salts from aqueous solution by plant fiber and cholestyramine. British Journal of Nutrition, 40 299-309. 1978.

18) Pulusani SR, Rao DR. Whole body, liver and plasma cholesterol levels in rats fed Thermophilus, Bulgaricus and Acidophilus milks. Journal of Food Science, $48: 280-281.1983$.

19) Rao DR, Chawan CB, Pulusani SR. Influence of milk and Thermophilus milk on plasma cholesterol levels and hepatic cholesterogenesis. Journal of Food 
Science, $46: 1339-1341.1981$.

20) Rodas BZ, Gilliand SE, Maxwell CV. Hypocholesterolemic action of Lactobacillus acidophillus ATCC 43121 and calcium in swine with hypercholesterolemia induced by diets. Journal of Dairy Science, $79: 2121-2128,1996$.

21) Salminen $S$, Deighton $M$ A, Benno $Y$, Gorbach SL. Lactic acid bacteria in health and disease. In : Lactic
Acid Bacteria. (Salminen S, von Wright eds.) 369386. A. Marcel Dekker, Inc. New York. 1997.

22) Vahouny GV, Tombes R, Cassidy MM, Kritchersky D, Gallo LL. Dietary fibers : V. Binding of bile salts, phospholipids and cholesterol from mixed micelles by bile acid sequestrates and dietary fibers. Lipids, 15 : 1012-1018. 1980. 